DOI: $10.15193 /$ zntj/2020/125/360

\author{
KAROLINA DOBA, MARTA CIEŚLAK, WOJCIECH ZMUDZIŃSKI
}

\title{
OCENA ZAWARTOŚCI WYBRANYCH MAKRO- I MIKROELEMENTÓW W MIODACH KOMERCYJNYCH ORAZ W MIODACH POCHODZĄCYCH BEZPOŚREDNIO Z PASIEKI
}

\begin{abstract}
Streszczenie
Miód charakteryzuje się unikatowymi właściwościami sensorycznymi i prozdrowotnymi. W skład miodu wchodzą między innymi przeciwutleniacze, enzymy, witaminy, makro- i mikroelementy, które kształtują jego aktywność biologiczną i odgrywają kluczową rolę w prawidłowym funkcjonowaniu organizmu. Miody stanowią źródło potasu, magnezu, wapnia, sodu, siarki, manganu, żelaza, wanadu, chromu, fosforu, srebra, boru i miedzi. Celem pracy było określenie składu mineralnego miodów odmianowych dostępnych na polskim rynku. W badaniach użyto polskich miodów różnych odmian: akacjowego, wielokwiatowego, lipowego i rzepakowego. Ocenie poddano miody zakupione w supermarkecie i pochodzące bezpośrednio z pasieki. Średnia zawartość $\mathrm{Ca}, \mathrm{K}, \mathrm{Na}, \mathrm{Mg}, \mathrm{Mn}, \mathrm{Zn}, \mathrm{Cu}$ i Fe w miodach wynosiła odpowiednio $[\mathrm{mg} / 100 \mathrm{~g}]: 7,42,59,66,1,57,1,44,0,11,0,46,0,02$ i 0,12 . Największą zawartością makroi mikroelementów charakteryzował się miód wielokwiatowy pochodzący bezpośrednio z pasieki $133,77 \mathrm{mg} / 100$ g. Najmniejszą zawartość składników mineralnych wykazano w miodzie akacjowym zakupionym w supermarkecie $-27,23 \mathrm{mg} / 100 \mathrm{~g}$. Dodatkowo przeanalizowano wpływ położenia prywatnej pasieki w okolicach Huty Miedzi Głogów na zawartość miedzi w próbach miodów różnych odmian. Nie stwierdzono statystycznie istotnej różnicy $(\mathrm{p} \geq 0,05)$ pomiędzy średnią zawartością miedzi w miodach komercyjnych i w miodach z prywatnej pasieki, co wskazuje na brak wpływu pochodzenia geograficznego na zawartość tego pierwiastka.
\end{abstract}

Słowa kluczowe: miód, jakość miodu, makroelementy, mikroelementy

\section{Wprowadzenie}

Do produktów pszczelich zalicza się: miód, mleczko, pierzgę, pyłek oraz wosk. Zgodnie z definicją zawartą w Rozporządzeniu Rady (WE) nr 1234/2007 z dnia 22 października 2007 r. [27] ,miód to naturalna słodka substancja wytwarzana przez pszczoły Apis mellifera z nektaru roślin lub wydzielin żywych części lub wydalin owa-

Mgr inż. K. Doba, mgr inż. M. Cieślak, dr hab. inż. W. Zmudziński, prof. UEP, Katedra Jakości i Bezpieczeństwa Żywności, Instytut Nauk o Jakości, Uniwersytet Ekonomiczny w Poznaniu, Al. Niepodległości 10,61-875 Poznań. Kontakt: karolina.doba@ue.poznan.pl 
dów wysysających żywe części roślin, zbieranych przez pszczoły, a następnie przerabianych przez łączenie specyficznych substancji pochodzących z organizmów pszczół, składanych, odwodnionych, gromadzonych i pozostawionych w plastrach do dojrzewania”. Ze względu na swoje unikatowe właściwości sensoryczne i odżywcze miód jest wykorzystywany głównie jako produkt do bezpośredniego spożycia, ale znajduje także zastosowanie w przemyśle spożywczym, np. w cukierniczym czy piekarniczym, ponadto $\mathrm{w}$ farmacji, medycynie, kosmetologii [7, 21]. Światowa produkcja miodu wynosi ok. 1,2 mln ton rocznie. Miody cechują się właściwościami przeciwdrobnoustrojowymi, przeciwzapalnymi, enzymatycznymi i prebiotycznymi [1, 19, 24]. Stosowane są w leczeniu ran i oparzeń oraz wspomagająco w chorobach układu krążenia, pokarmowego i oddechowego. Miody charakteryzują się dużym zróżnicowaniem ze względu na właściwości i skład chemiczny, co jest związane przede wszystkim z rodzajem surowca, jego pochodzeniem botanicznym i geograficznym, czynnikami środowiskowymi i klimatycznymi oraz przebiegiem procesu pozyskiwania i dojrzewania. Wyróżnia się miody nektarowe, spadziowe i nektarowo-spadziowe [7, 21, 25, 26].

Węglowodany stanowią ok. 80 \% wszystkich związków chemicznych obecnych w miodach. Do monosacharydów zalicza się glukozę (ok. 30 \%) i fruktozę (ok. 35 \%) [26]. W skład miodów wchodzą także disacharydy, trisacharydy oraz oligosacharydy, które charakteryzują się właściwościami prebiotycznymi i zdolnością do stymulacji rozwoju pałeczek mlekowych z rodzaju Lactobacillus [19]. W wyniku przemiany cukrów prostych na skutek dehydratacji zachodzącej w środowisku kwasowym lub w czasie reakcji Maillarda powstaje 5-hydroksymetylofurfural, który cechuje się mutagennością i genotoksycznością. Właściwości sensoryczne miodów są związane z obecnością kwasów organicznych, których zawartość jest zmienna w czasie dojrzewania [2, $16,17,19]$. Na aromat miodu wpływają olejki eteryczne pochodzące przede wszystkim z nektaru [11]. Czynnikami w dużej mierze kształtującymi bioaktywność miodu są mikro- i makroelementy, witaminy, hormony pszczele, enzymy oraz związki polifenolowe $[1,8,19,23]$. Do przeciwutleniaczy występujących w miodach zalicza się: flawony, flawonoidy, izoflawony, fenolokwasy, karotenoidy, katechiny, antocyjany, kwas askorbinowy, przeciwutleniacze enzymatyczne i tokoferol $[1,8,19]$. Stwierdzono pozytywną korelację pomiędzy zawartością przeciwutleniaczy $\mathrm{w}$ badanych próbkach miodów a ich właściwościami przeciwbakteryjnymi w stosunku do wybranych bakterii Gram-dodatnich i Gram-ujemnych [8, 23, 24]. Największą zawartością przeciwutleniaczy charakteryzują się miody ciemne $[13,16]$. Niewielka zawartość witamin $\mathrm{C}, \mathrm{A}, \mathrm{B}_{1}$, $\mathrm{B}_{2}, \mathrm{~B}_{6}, \mathrm{~K}$ i E występujących w miodach nie odgrywa istotnej roli w diecie człowieka z uwagi na średnie roczne spożycie miodu w Polsce wynoszące ok. 0,26 kg. Dla porównania Niemcy spożywają ok. $1,2 \mathrm{~kg}$ miodu rocznie $[5,6,10]$.

Prawidłowe funkcjonowanie organizmu ludzkiego wymaga dostarczania wraz z dietą niezbędnych składników mineralnych. Składniki te pełnią kluczową funkcję 
w aktywności enzymów o działaniu przeciwutleniającym, które stanowią mechanizm obronny przed uszkodzeniem komórek spowodowanym wolnymi rodnikami. Niedostateczna podaż mikro- i makroelementów wiąże się z zaburzeniami w funkcjonowaniu organizmu i może prowadzić do wielu chorób. Zawartość składników mineralnych w miodach kształtuje się na poziomie $0,02 \div 0,4 \%$. Miody stanowią źródło magnezu, wapnia, potasu, sodu, manganu, żelaza, wanadu, chromu, fosforu, srebra, boru i miedzi [7, 21, 25]. Sód m.in. odgrywa rolę w utrzymaniu potencjału czynnościowego błon komórkowych. Potas odpowiada za regulację gospodarki kwasowo-zasadowej. Magnez bierze udział w aktywacji wielu enzymów, a z wapniem przeciwdziałają skurczowi mięśni. Wapń dodatkowo uczestniczy w procesie krzepnięcia krwi. Mangan pełni funkcję kofaktora enzymów i wpływa na stabilizację poziomu cukru we krwi. Cynk bierze udział w procesie gojenia się ran, jest składnikiem wielu enzymów oraz reguluje wydzielanie insuliny. Regularne spożywanie miodu może przyczyniać się do uzupełniania niedoborów niektórych pierwiastków w diecie, w szczególności manganu i żelaza [12]. Pierwiastki, takie jak chrom, żelazo czy miedź wchodzą w skład enzymów i odpowiadają za metabolizm tłuszczów oraz węglowodanów, jak również za utrzymywanie odporności komórkowej. Ich nadmierne spożycie wiąże się jednak z działaniem toksycznym. Najchętniej spożywanymi odmianami są miody rzepakowe, akacjowe, lipowe, gryczane, spadziowe i wielokwiatowe. Około $70 \%$ polskich konsumentów najchętniej wybiera miody nektarowe jednokwiatowe [10]. Miody wielokwiatowe i akacjowe charakteryzują się dużą zawartością żelaza, chloru, wapnia, sodu, potasu, jodu i magnezu. Miód rzepakowy ma jasną barwę i zawiera stosunkowo mało składników mineralnych. Miody gryczane charakteryzują się intensywnym smakiem oraz zapachem i stanowią źródło miedzi, krzemu, cynku, żelaza, boru i fosforu. Miód spadziowy jest produktem powstającym z wydalin owadów, które wysysają żywe części roślin lub z wydzielin żywych części roślin, które są zbierane przez pszczoły, zawiera dużo mikro- i makroelementów oraz cechuje się ciemną barwą i silnymi właściwościami przeciwutleniającymi $[13,16]$. Intensywna barwa miodu może być także wynikiem celowego lub przypadkowego podgrzania lub starzenia się produktu. Do najważniejszych czynników kształtujących jakość miodów zalicza się: pochodzenie botaniczne i geograficzne oraz praktykę pszczelarską [7, 21, 25, 26]. Pszczoły i miód można traktować jako wskaźniki stanu zanieczyszczenia środowiska, np. metalami ciężkimi. Wskazuje się na dodatnią korelację pomiędzy zawartością metali ciężkich w miodach a poziomem zanieczyszczenia środowiska $[18,21,25$.$] . W niektórych pu-$ blikacjach podaje się w wątpliwość istnienie takiej tendencji. Zwraca się uwagę, że położenie pasiek w okolicach kopalń, czyli na terenach zanieczyszczonych, nie wpływa na zwiększenie zawartości metali ciężkich w produktach pszczelich, tj. w miodzie i pyłku pszczelim [4]. 
Celem pracy było określenie zawartości wybranych mikro- i makroelementów w polskich miodach różnych odmian, dostępnych w sieci sklepów spożywczych i pochodzących bezpośrednio z pasieki. Dodatkowo ocenie poddano wpływ położenia pasieki w okolicy Huty Miedzi Głogów na zawartość miedzi w miodach.

\section{Material i metody badań}

Przedmiotem badań było 8 miodów pszczelich zróżnicowanych ze względu na pochodzenie botaniczne i geograficzne. Cztery próbki miodów zakupiono w supermarkecie na terenie Poznania. a cztery kolejne pozyskano bezpośrednio z pasieki prywatnej położonej w gminie Grębocice (powiat głogowski, województwo dolnośląskie). Miody pochodziły z województw małopolskiego (RS, WS) i śląskiego (AS, LS, RP, LP, WP) - tab. 1. Analizie poddano miody wielokwiatowe, akacjowe, rzepakowe i lipowe. Do chwili przeprowadzenia badań miody przechowywano w szczelnych, szklanych opakowaniach w warunkach chłodniczych, bez dostępu powietrza i światła.

Tabela 1. Charakterystyka badanych miodów

Table 1. Characteristics of analysed honeys

\begin{tabular}{|c|c|c||}
\hline Miód / Honey & $\begin{array}{c}\text { Symbol próby } \\
\text { Symbol of sample }\end{array}$ & Pochodzenie / Origin \\
\hline Akacjowy / Acacia & AS & Supermarket \\
\hline Rzepakowy / Rapeseed & RS & Supermarket \\
\hline Lipowy / Lime & LS & Supermarket \\
\hline Wielokwiatowy / Multifloral & WS & Pasiekarket \\
\hline Akacjowy / Acacia & AP & Pasieka prywatna / Private apiary \\
\hline Rzepakowate apiary \\
\hline Lipowy / Lime & RP & Pasieka prywatna / Private apiary \\
\hline Wielokwiatowy / Multifloral & WP & Pasieka prywatna / Private apiary \\
\hline
\end{tabular}

W miodach oznaczano makro- i mikroelementy z zastosowaniem atomowej spektrometrii emisyjnej z plazmą mikrofalową (Agilent 4210, Agilent Technologies, USA).

Próbki badanych miodów $(2,5 \pm 0,0001 \mathrm{~g})$ odważano do szklanych zlewek i dodawano $5 \mathrm{~cm}^{3}$ gorącej wody redestylowanej, następnie dokładnie mieszano aż do całkowitego rozpuszczenia się miodu i przenoszono ilościowo do probówek przeznaczonych do mineralizacji „na mokro”. Próbki poddawano mineralizacji z dodatkiem $20 \mathrm{~cm}^{3}$ 65-procentowego kwasu azotowego(V) (cz.d.a) i $1 \mathrm{~cm}^{3}$ nadtlenku wodoru (33\%). Mineralizację prowadzono w mineralizatorze SpeedDigester K-425 (Büchi, Szwajcaria) w temp. $240{ }^{\circ} \mathrm{C}$ przez 90 min. Jednocześnie przygotowywano i analizowano próby zerowe. Zmineralizowane próbki rozcieńczano wodą redestylowaną w kolbach miarowych o pojemności $50 \mathrm{~cm}^{3} \mathrm{z}$ tworzywa sztucznego, a następnie oznaczano 
pierwiastki. Współczynniki korelacji liniowej (r) krzywych wzorcowych przygotowanych dla poszczególnych pierwiastków wynosiły 0,999.

Otrzymane wyniki opracowano statystycznie z wykorzystaniem pakietu Microsoft Excel. W celu zweryfikowania istotności różnic pomiędzy średnimi zawartościami miedzi $\mathrm{w}$ miodach odmianowych zakupionych $\mathrm{w}$ supermarkecie oraz pochodzących z prywatnej pasieki wykonano test t-Studenta. Wyniki badań stanowią średnią z co najmniej trzech przeprowadzonych oznaczeń.

\section{Wyniki i dyskusja}

Wyniki oznaczania zawartości makro- i mikroelementów w badanych miodach przedstawiono w tab. 2 .

Tabela 2. Zawartość makro- i mikroelementów w badanych miodach

Table 2. Content of macro- and microelements in analysed honeys

\begin{tabular}{|c|c|c|c|}
\hline $\begin{array}{c}\text { Symbol próby } \\
\text { Symbol of } \\
\text { sample }\end{array}$ & $\begin{array}{c}\text { Pierwiastek } \\
\text { Element }\end{array}$ & $\begin{array}{c}\text { Zawartość pierwiastka } \\
\text { Content of element }[\mathrm{mg} / 100 \mathrm{~g}]\end{array}$ & $\begin{array}{c}\text { Względne odchylenie } \\
\text { standardowe } \\
\text { Relative standard } \\
\text { deviation [\%] }\end{array}$ \\
\hline \multicolumn{3}{|c|}{ Miody z supermarketu / Honeys from supermarket } \\
\hline \multirow{4}{*}{ AS } & $\mathrm{K}$ & $12,03 \pm 0,34$ & 2,87 \\
& $\mathrm{Na}$ & $8,15 \pm 0,12$ & 1,46 \\
& $\mathrm{Mg}$ & $2,01 \pm 0,04$ & 2,10 \\
& $\mathrm{Ca}$ & $4,49 \pm 0,24$ & 0,41 \\
& $\mathrm{Mn}$ & $0,02 \pm 0,00$ & 1,99 \\
& $\mathrm{Fe}$ & $0,12 \pm 0,02$ & 5,45 \\
& $\mathrm{Cu}$ & $0,01 \pm 0,00$ & 3,62 \\
& $\mathrm{Zn}$ & $0,40 \pm 0,01$ & 2,95 \\
\hline \multirow{5}{*}{$\mathrm{RS}$} & $\mathrm{K}$ & $34,07 \pm 0,58$ & 1,71 \\
& $\mathrm{Na}$ & $0,90 \pm 0,04$ & 1,70 \\
& $\mathrm{Mg}$ & $0,83 \pm 0,03$ & 4,12 \\
& $\mathrm{Ca}$ & $7,30 \pm 0,32$ & 4,33 \\
& $\mathrm{Mn}$ & $0,07 \pm 0,00$ & 1,64 \\
& $\mathrm{Fe}$ & $<\mathrm{LOD}$ & - \\
& $\mathrm{Cu}$ & $0,02 \pm 0,00$ & 5,96 \\
$\mathrm{Zn}$ & $0,43 \pm 0,03$ & 7,82 \\
\hline \multirow{5}{*}{$\mathrm{K}$} & $\mathrm{K}$ & $97,54 \pm 5,18$ & 5,31 \\
& $\mathrm{Na}$ & $0,55 \pm 0,01$ & 2,13 \\
& $\mathrm{Mg}$ & $1,22 \pm 0,03$ & 2,45 \\
& $\mathrm{Ca}$ & $9,17 \pm 0,40$ & 4,34 \\
& $\mathrm{Mn}$ & $0,08 \pm 0,00$ & 4,12 \\
& $\mathrm{Fe}$ & $<\mathrm{LOD}$ & - \\
& $\mathrm{Cu}$ & $0,02 \pm 0,00$ & 2,37 \\
& $\mathrm{Zn}$ & $0,45 \pm 0,01$ & 2,06 \\
\hline
\end{tabular}




\begin{tabular}{|c|c|c|c|}
\hline WS & $\begin{array}{c}\mathrm{K} \\
\mathrm{Na} \\
\mathrm{Mg} \\
\mathrm{Ca} \\
\mathrm{Mn} \\
\mathrm{Fe} \\
\mathrm{Cu} \\
\mathrm{Zn} \\
\end{array}$ & $\begin{array}{c}46,66 \pm 0,30 \\
0,42 \pm 0,03 \\
1,77 \pm 0,05 \\
10,07 \pm 0,56 \\
0,05 \pm 0,00 \\
<\text { LOD } \\
0,02 \pm 0,00 \\
0,40 \pm 0,02 \\
\end{array}$ & $\begin{array}{c}0,65 \\
5,91 \\
2,87 \\
5,60 \\
5,56 \\
- \\
2,85 \\
5,13 \\
\end{array}$ \\
\hline \multicolumn{4}{|c|}{ Miody z prywatnej pasieki / Honeys from private apiary } \\
\hline AP & $\begin{array}{c}\mathrm{K} \\
\mathrm{Na} \\
\mathrm{Mg} \\
\mathrm{Ca} \\
\mathrm{Mn} \\
\mathrm{Fe} \\
\mathrm{Cu} \\
\mathrm{Zn} \\
\end{array}$ & $\begin{array}{c}33,79 \pm 0,90 \\
0,34 \pm 0,02 \\
0,61 \pm 0,03 \\
4,48 \pm 0,02 \\
0,03 \pm 0,00 \\
<\text { LOD } \\
0,02 \pm 0,00 \\
0,54 \pm 0,05 \\
\end{array}$ & $\begin{array}{c}2,66 \\
4,48 \\
5,44 \\
0,41 \\
2,59 \\
- \\
5,76 \\
5,95 \\
\end{array}$ \\
\hline $\mathrm{RP}$ & $\begin{array}{c}\mathrm{K} \\
\mathrm{Na} \\
\mathrm{Mg} \\
\mathrm{Ca} \\
\mathrm{Mn} \\
\mathrm{Fe} \\
\mathrm{Cu} \\
\mathrm{Zn}\end{array}$ & $\begin{array}{c}40,67 \pm 0,14 \\
0,44 \pm 0,03 \\
1,01 \pm 0,06 \\
6,31 \pm 0,21 \\
0,02 \pm 0,00 \\
<\text { LOD } \\
0,02 \pm 0,00 \\
0,57 \pm 0,05\end{array}$ & $\begin{array}{c}0,34 \\
6,08 \\
5,77 \\
3,36 \\
3,65 \\
- \\
7,06 \\
8,15\end{array}$ \\
\hline LP & $\begin{array}{c}\mathrm{K} \\
\mathrm{Na} \\
\mathrm{Mg} \\
\mathrm{Ca} \\
\mathrm{Mn} \\
\mathrm{Fe} \\
\mathrm{Cu} \\
\mathrm{Zn} \\
\end{array}$ & $\begin{array}{c}93,86 \pm 0,97 \\
0,84 \pm 0,05 \\
1,46 \pm 0,07 \\
6,44 \pm 0,30 \\
0,31 \pm 0,01 \\
<\text { LOD } \\
0,02 \pm 0,00 \\
0,54 \pm 0,03\end{array}$ & $\begin{array}{c}1,03 \\
5,61 \\
4,79 \\
4,68 \\
4,76 \\
- \\
5,31 \\
5,95 \\
\end{array}$ \\
\hline WP & $\begin{array}{c}\mathrm{K} \\
\mathrm{Na} \\
\mathrm{Mg} \\
\mathrm{Ca} \\
\mathrm{Mn} \\
\mathrm{Fe} \\
\mathrm{Cu} \\
\mathrm{Zn}\end{array}$ & $\begin{array}{c}118,64 \pm 5,82 \\
0,90 \pm 0,02 \\
2,38 \pm 0,10 \\
11,07 \pm 0,17 \\
0,34 \pm 0,00 \\
<\text { LOD } \\
0,04 \pm 0,00 \\
0,38 \pm 0,01\end{array}$ & $\begin{array}{c}4,91 \\
4,40 \\
4,18 \\
1,52 \\
0,39 \\
- \\
3,09 \\
3,55\end{array}$ \\
\hline
\end{tabular}

Objaśnienia / Explanatory notes:

Symbole miodów jak w tab. 1. / Symbols of honeys as in Tab. 1. W tabeli przedstawiono wartości średnie \pm odchylenia standardowe / Table shows mean values \pm standard deviations. 
Polskie miody odmianowe są zróżnicowane ze względu na zawartość mikroi makroelementów. Najwyższym poziomem wapnia charakteryzowały się miody wielokwiatowe zarówno z prywatnej pasieki, jak i pochodzące z supermarketu. Zawartość tego pierwiastka wynosiła odpowiednio: 11,07 i 10,7 mg/100 g. Średnia zawartość Ca w badanych próbach wynosiła $7,42 \mathrm{mg} / 100 \mathrm{~g}$. Najniższy poziom wapnia stwierdzono w miodach akacjowych (ok. 4,5 mg/100 g). Podobną średnią zawartością wapnia charakteryzowały się miody włoskie $\mathrm{z}$ regionu Lacjum (ok. 4,77 mg/100 g) $[5,6]$. W przypadku miodów pochodzących z terenu Węgier średnia zawartość wapnia kształtowała się na poziomie $4,15 \mathrm{mg} / 100 \mathrm{~g}$ [4].

Najwyższym poziomem magnezu charakteryzowała się próbka miodu wielokwiatowego z prywatnej pasieki $(2,38 \mathrm{mg} / 100 \mathrm{~g})$. Średnia zawartość $\mathrm{Mg}$ w miodach będących przedmiotem badań wynosiła $1,41 \mathrm{mg} / 100$ g. Według Kędzierskiej-Matysek i wsp. [12] średnia zawartość tego pierwiastka w polskich miodach wielokwiatowych to $6,16 \mathrm{mg} / 100 \mathrm{~g}$. Najniższy poziom $\mathrm{Mg}$ autorzy odnotowali w polskich miodach akacjowych $-0,88 \mathrm{mg} / 100 \mathrm{~g}$. W badaniach przeprowadzonych przez Stecką i wsp. [22] średnia zawartość magnezu w komercyjnych miodach spadziowych i nektarowych zakupionych na terenie Polski wynosiła 2,29 mg/100 g [22], a najwyższy poziom tego pierwiastka wykazano w miodzie ze spadzi liściastej $(13,85 \mathrm{mg} / 100 \mathrm{~g})$ [22].

Pierwiastkiem występującym w największej ilości w badanych polskich miodach był potas. Stanowił on $44 \div 91 \%$ wszystkich mikro- i makroelementów w analizowanych próbach. Najwyższym poziomem potasu charakteryzował się miód wielokwiatowy pozyskany z prywatnej pasieki - 118,64 mg/100 g. Spośród przebadanych prób najmniejszą zawartością potasu cechował się miód akacjowy z supermarketu. Średnia zawartość potasu wynosiła w nim 12,03 mg/100 g. Odmienne wyniki uzyskali Kędzierska-Matysek i wsp. [12]. Stwierdzona przez nich średnia zawartość potasu w polskich miodach wielokwiatowych wynosiła $43,23 \mathrm{mg} / 100 \mathrm{~g}$, natomiast w miodach akacjowych 24,22 mg/100 g. W badaniach przeprowadzonych przez Madejczyk i Barałkiewicz [14] średnią zawartość potasu w polskich miodach spadziowych i rzepakowych określono na poziomie $123,3 \mathrm{mg} / 100 \mathrm{~g}$ [14]. W przypadku miodów pochodzących z Węgier Bodó i wsp. [4] odnotowali średnią zawartość tego pierwiastka w odmianie wielokwiatowej na poziomie $46 \mathrm{mg} / 100 \mathrm{~g}$ [4]. Według analiz przeprowadzonych przez Bilandžića i wsp. [3] miody nektarowe z Chorwacji zawierały potas na poziomie $23,0 \div 46,4 \mathrm{mg} / 100 \mathrm{~g}$.

Największą zawartością sodu charakteryzował się miód akacjowy dostępny w supermarkecie $(8,15 \mathrm{mg} / 100 \mathrm{~g})$. Srednia zawartość tego pierwiastka w badanych miodach wynosiła $1,57 \mathrm{mg} / 100 \mathrm{~g}$. Podobną średnią zawartość sodu w miodach wielokwiatowych stwierdzili wcześniej Bodó i wsp. [4] w miodach pochodzących z Węgier (1,3 mg sodu w $100 \mathrm{~g})$. Najniższy poziom sodu oznaczono w miodzie akacjowym pochodzącym z prywatnej pasieki $(0,34 \mathrm{mg} / 100 \mathrm{~g})$. Serbskie miody akacjowe charaktery- 
zowały się średnią zawartością sodu na poziomie $0,5 \mathrm{mg} / 100 \mathrm{~g}$ [20]. Podobny wynik otrzymano w przypadku miodu lipowego z supermarketu.

Zawartość cynku w badanych miodach wynosiła od $0,38 \mathrm{mg} / 100 \mathrm{~g}$ (miód wielokwiatowy z prywatnej pasieki) do $0,57 \mathrm{mg} / 100 \mathrm{~g} \mathrm{w}$ miodzie rzepakowym (RP) z województwa śląskiego. Zalecane dzienne spożycie cynku wynosi od 8 do $11 \mathrm{mg}$. Źródłem występowania cynku w środowisku naturalnym jest przede wszystkim działalność człowieka. Obecność tego pierwiastka w miodzie jest spowodowana jego transferem z gleby poprzez system korzeniowy, łodygi i kwiaty. Proces ten jest zależny od kwasowości gleby, zawartości w niej substancji organicznych oraz stadium rozwojowego rośliny [18]. Popek [18] odnotował średnią zawartość cynku w analizowanych próbach na poziomie od $0,8 \mathrm{mg} / 100 \mathrm{~g} \mathrm{w}$ miodzie akacjowym do $1,8 \mathrm{mg} / 100 \mathrm{~g}-$ w miodzie wrzosowym, przy czym średnią zawartość cynku w badanych miodach określił jako 1,23 mg/100 g. Najmniejszą zawartością tego pierwiastka charakteryzowały się miody lipowe i akacjowe. Nie stwierdzono zależności pomiędzy zawartością cynku w miodach a ich pochodzeniem geograficznym. Wysoki poziom cynku w miodzie może być związany z jego nieprawidłowym przechowywaniem lub przypadkowym zanieczyszczeniem np. w wyniku stosowania do magazynowania produktu naczyń ocynkowanych. Nieodpowiednie przechowywanie może powodować migrację tego pierwiastka i wpływać na jego zwiększone stężenie w produkcie, w szczególności w przypadku miodów, które charakteryzują się wysoką kwasowością [18].

Zawartość manganu w badanych miodach wynosiła $0,02 \div 0,34 \mathrm{mg} / 100 \mathrm{~g}$, przy czym tę górną granicę wykazano $\mathrm{w}$ miodzie wielokwiatowym pochodzącym z prywatnej pasieki. Średnia zawartość manganu w badanych próbach to $0,12 \mathrm{mg} / 100 \mathrm{~g}$. Węgierskie miody wielokwiatowe zawierały średnio $0,037 \mathrm{mg} \mathrm{Mn} \mathrm{w} 100 \mathrm{~g}$, a rzepakowe - na poziomie $0,02 \mathrm{mg} / 100 \mathrm{~g}$ [4]. Kędzierska-Matysek i wsp. [12] określili mangan na poziomie $0,21 \mathrm{mg} \mathrm{w} 100 \mathrm{~g}$ miodu.

W badaniach własnych największą zawartość miedzi stwierdzono w miodzie wielokwiatowym z prywatnej pasieki $(0,04 \mathrm{mg} / 100)$, a średnia zawartość $\mathrm{Cu}$ w badanych próbach wynosiła $0,02 \mathrm{mg} / 100 \mathrm{~g}$. Zawartość miedzi w chorwackich miodach nektarowych, oznaczona przez Bilandžića i wsp. [3], była bardzo zróżnicowana i wynosiła $0,007 \div 0,12 \mathrm{mg} / 100 \mathrm{~g} \mathrm{w}$ zależności od ich pochodzenia botanicznego i geograficznego [3]. Conti i wsp. [5] średnią zawartość miedzi w miodach odmianowych pochodzących z północy Włoch określili na poziomie $0,031 \mathrm{mg} / 100 \mathrm{~g}$.

Miód stanowi produkt bioakumulacji składników toksycznych i może być źródłem informacji o stanie ekosystemu, w którym bytują owady. Analiza poziomu metali ciężkich, w tym miedzi, pozwala na ocenę stopnia zanieczyszczenia terenu, z którego pozyskano produkt. Nie stwierdzono jednak istotnej zależności pomiędzy średnią zawartością miedzi $\mathrm{w}$ miodach odmianowych pochodzących $\mathrm{z}$ prywatnej pasieki oraz zakupionych w supermarkecie $(\mathrm{p} \geq 0,05)$. Zalecane dzienne spożycie miedzi kształtuje 
się na poziomie $0,9 \mathrm{mg}$. Poziom miedzi w polskich miodach mieścił się $\mathrm{w}$ zakresie $0,01 \div 0,04 \mathrm{mg} / 100 \mathrm{~g}$. W tab. 3. przedstawiono wyniki analiz średniej zawartości miedzi w badanych próbach miodów płynnych.

Tabela 3. Zawartość miedzi w badanych miodach

Table 3. Content of copper in analysed honeys

\begin{tabular}{||c|c||}
\hline Symbol próby / Symbol of sample & Zawartość $\mathrm{Cu} /$ Content of $\mathrm{Cu}[\mathrm{mg} / 100 \mathrm{~g}]$ \\
\hline AS & $0,01 \pm 0,00$ \\
\hline RS & $0,02 \pm 0,00$ \\
\hline LS & $0,02 \pm 0,00$ \\
\hline WS & $0,02 \pm 0,00$ \\
\hline AP & $0,02 \pm 0,00$ \\
\hline RP & $0,02 \pm 0,00$ \\
\hline LP & $0,02 \pm 0,00$ \\
\hline WP & $0,04 \pm 0,00$ \\
\hline
\end{tabular}

Objaśnienia / Explanatory notes:

Symbole miodów jak w tab. 1. / Symbols of honeys as in Tab. 1. W tabeli przedstawiono wartości średnie \pm odchylenia standardowe / Table shows mean values \pm standard deviations. Wartości średnie nie różnią się statystycznie istotnie $(p \geq 0,05) /$ mean values do not differ statistically significantly at $p \geq 0.05$.

Spośród wszystkich przebadanych prób zawartość żelaza na poziomie $0,12 \mathrm{mg} / 100 \mathrm{~g}$ stwierdzono jedynie w miodzie akacjowym pochodzącym z supermarketu. Wartość ta była znacznie niższa od średniej zawartości Fe $(0,36 \mathrm{mg} / 100 \mathrm{~g}) \mathrm{w}$ polskich miodach badanych przez Kędzierską-Matysek i wsp. [12]. Według Formickiego i wsp. [9] zawartość żelaza w miodach pochodzących z województwa małopolskiego wynosiła $0,8 \div 2,4 \mathrm{mg} / 100 \mathrm{~g}$. Biorąc pod uwagę zalecane dzienne spożycie Fe $(10 \div 18 \mathrm{mg})$, konsumpcja miodu nie przyczynia się w znaczący sposób do pokrycia dziennego zapotrzebowania organizmu na ten pierwiastek. Żelazo zawarte w miodzie charakteryzuje się jednak dużą biodostępnością [22].

\section{Wnioski}

1. Największą ogólną zawartość mikro- i makroelementów stwierdzono w miodzie wielokwiatowym pochodzącym bezpośrednio z pasieki - 133,77 mg/100 g, najmniejszą $-27,32 \mathrm{~g} / 100 \mathrm{~g}$ w miodzie akacjowym zakupionym w supermarkecie.

2. Pomimo zróżnicowanej zawartości mikro- i makroelementów w badanych miodach nie można jednoznacznie określić ich pochodzenia botanicznego i geograficznego na podstawie składu mineralnego.

3. Nie stwierdzono istotnej różnicy pomiędzy średnimi zawartościami miedzi w miodach odmianowych zakupionych w supermarkecie i pochodzących z prywatnej pa- 
sieki położonej w okolicy Huty Miedzi Głogów, co wskazuje na brak wpływu pochodzenia geograficznego na zawartość tego pierwiastka.

Badania sfinansowano ze środków Ministerstwa Nauki i Szkolnictwa Wyższego otrzymanych w ramach dotacji na utrzymanie potencjatu badawczego Instytutu Nauk o Jakości Uniwersytetu Ekonomicznego w Poznaniu.

\section{Literatura}

[1] Alves A., Ramos A., Goncalves M., Bernardo M., Mendes B.: Antioxidant activity, quality parameters and mineral content of Portuguese monofloral honeys. J. Food Comp. Anal., 2013, 30, 130-138.

[2] Ana N., Cai W.-J., Zhu Q.-F., Wang W., Hussain D., Feng Y.-Q.: Metabolic profiling of organic acids in honey by stable isotope labelling assisted liquid chromatography-mass spectrometry. J. Food Comp. Anal., 2020, 87, \#103423.

[3] Bilandžić N., Sedak M., Dokić M., Gross Bošković A., Florijančić T., Bošković I., Kovačić M., Puškadija Z., Hruškar M.: Element content in ten Croatian honey types from different geographical regions during three seasons. J. Food Comp. Anal., 2019, 84, \#103305.

[4] Bodó A., Radvány L., Kőszegi T., Csepregi R., Nagya D., Farkas A., Kocsis M.: Melissopalynology, antioxidant activity and multielement analysis of two types of early spring honeys from Hungary. Food Bioscience, 2020, 35, \#100587.

[5] Conti M.E., Saccares S., Cubadda F., Cavallina R., Tenoglio C.A., Ciprotti L.: Miele nel Lazio: Indagine sul contenuto in metallic in trace e radionuclide. Rivisita di Scienza dell Alimentazione, 1998, 192, 107-109.

[6] Conti M.E.: Lazio region (central Italy) honeys: A survey of mineral content and typical quality parameters. Food Control, 2000, 11, 459-463.

[7] Dżugan M., Ruszel A., Tomczyk M.: Jakość miodów importowanych dostępnych na rynku podkarpackim. Żywność. Nauka. Technologia. Jakość, 2018, 4 (117), 127-139.

[8] Fernandes L., Ribeiro H., Oliveira A., Sanches Silva A., Freitas A., Henriques M., Rodrigues M.: Portuguese honeys as antimicrobial agents against Candida species. J. Trad. Complem. Med., 2020, 9 (2), 130-136.

[9] Formicki G., Greń A., Stawarz R., Zyśk B., Gał A.: Metal content in honey, propolis, wax, and bee pollen and implications for metal pollution monitoring. Pol. J. Environ. Stud., 2013, 22 (1), 99-106.

[10] Gontarz A., Błońska I., Socha S.: Analiza preferencji konsumenckich studentów dotycząca miodów pszczelich. Wiadomości Zootechniczne, 2016, 4, 61-76.

[11] Jasicka-Misiak I., Kafarski P.: Chemiczne markery miodów odmianowych. Chemik, 2014, 68 (4), 335-340.

[12] Kędzierska-Matysek M., Litwińczuk Z., Koperska N., Barłowska J.: Zawartość makro- i mikroelementów w miodach pszczelich z uwzględnieniem odmiany oraz kraju pochodzenia. Nauka Przyr. Technol., 2013, 7 (3), 1-10.

[13] Kędzierska-Matysek M., Florek M., Wolanciuk A., Barłowska J.: Współzależności pomiędzy parametrami barwy w systemie CIE i zawartością składników mineralnych w miodach pszczelich, Annales UMCS sectio EE Zootechnica, 2017, XXXV (4), 17-26.

[14] Madejczyk M., Barałkiewicz D.: Characterization of Polish rape and honeydew honey according to their mineral contents using ICP-MS and F-AAS/AES. Analytica Chimica Acta, 2008, 617, 11-17.

[15] Majewska E.: Porównanie wybranych właściwości miodów pszczelich jasnych i ciemnych. Nauka Przyr. Technol., 2009, 3 (4), 1-9. 
[16] Majewska E., Kowalska J., Jeżowska A.: Charakterystyka jakości miodów wielokwiatowych z różnych regionów polski. Bromat. Chem. Toksykol., 2010, 3, 391-397.

[17] Popek S.: Badanie kwasowości pszczelich miodów odmianowych. Zesz. Nauk. AE w Krakowie, 2003, 623, 29-33.

[18] Popek S.: Badanie zawartości cynku w pszczelich miodach odmianowych. Zesz. Nauk. AE w Krakowie, 2006, 705, 51-56.

[19] Rosiak E., Jaworska D.: Właściwości probiotyczne i prebiotyczne miodów pszczelich w aspekcie ich jakości i bezpieczeństwa zdrowotnego. Żywność. Nauka. Technologia. Jakość, 2019, 3 (120), 36-48.

[20] Sakač M., Jovanov P., Marić A., Pezo L., Kevrešan Ž., Novaković A., Nedeljković N.: Physicochemical properties and mineral content of honey samples from Vojvodina (Republic of Serbia). Food Chem., 2019, 276, 15-21.

[21] Sixto A., Mollo A., Knochen M.: Fast and simple method using DLLME and FAAS for the determination of trace cadmium in honey. J. Food Comp. Anal., 2019, 82, 1-6.

[22] Stecka H., Gręda K., Pohl P.: Zawartość i biodostępność wapnia, miedzi, żelaza, magnezu, manganu i cynku w komercyjnie dostępnych krajowych miodach pszczelich. Bromat. Chem. Toksykol., 2012, 2, 111-116.

[23] Wantusiak P.M., Piszcz P., Skwarek M., Głód B.K.: Właściwości antyoksydacyjne miodów wyznaczone metodami chromatograficznymi. Camera Separatoria, 2011, 3 (2), 297-317.

[24] Wilczyńska A.: Metody oznaczania aktywności antyoksydacyjnej miodów pszczelich. Bromat. Chem. Toksykol., 2009, 3, 870-874.

[25] Zamanian M., Azizi-Soleiman F.: Honey and glycemic control: A systematic review. Pharma Nutrition, 2020, 11, \#100180.

[26] Zielińska S., Wesołowska M., Bilek M., Kaniuczak J., Dżugan M.: The saccharide profile of Polish honeys depending on their botanical origin. J. Microbiol. Biotech. Food Sci., 2014, 3 (5), 387-390.

[27] Rozporządzenie Rady (WE) nr 1234/2007 z dnia 22 października 2007 r. ustanawiające wspólną organizację rynków rolnych oraz przepisy szczegółowe dotyczące niektórych produktów rolnych (rozporządzenie o jednolitej wspólnej organizacji rynku). Dz. U. L 299, s. 1-149, z 16.11.2007.

\section{ASSESSING CONTENT OF SELECTED MACRO- AND MICROELEMENTS IN COMMERCIAL HONEYS AND IN HONEYS DERIVED DIRECTLY FROM APIARY}

\section{S u m m a ry}

Honey is characterised by unique sensory and health-promoting properties. It contains inter alia antioxidants, enzymes, vitamins and macro- and microelements that shape its biological activity and play an important role in the proper functioning of human body. Honeys are a source of potassium, magnesium, calcium, sodium, sulphur, manganese, iron, vanadium, chromium, phosphorus, silver, boron and copper. The objective of the research study was to determine the mineral composition of varietal honeys available on the Polish market. In the research study there were analysed Polish honeys of various varieties: acacia, multifloral, lime and rapeseed. Assessed were honeys purchased in a supermarket and derived directly from an apiary. The average content of $\mathrm{Ca}, \mathrm{K}, \mathrm{Na}, \mathrm{Mg}, \mathrm{Mn}, \mathrm{Zn}, \mathrm{Cu}$ and $\mathrm{Fe}$ in honeys was, respectively [mg/100 g]: 7.42, 59.66, 1.57, 1.44, 0.11, 0.46, 0.02 and 0.12 . The highest content of macro- and micronutrients was found in the multifloral honey derived directly from the apiary $-133.77 \mathrm{mg} / 100 \mathrm{~g}$. The lowest content of mineral components was determined in the acacia honey purchased in the supermarket $27.32 \mathrm{mg} / 100 \mathrm{~g}$. Additionally, there was studied the effect of location of a private apiary situated near the Głogów Copper Smelter on the content of copper in the samples of honeys of different varieties. No sig- 
nificant relationship was found ( $\mathrm{p} \geq 0.05$ ) between the average content of copper in the commercial honeys and those from the private apiary, which indicates no influence of geographical origin on the content of this element.

Key words: honey, honey quality, macroelements, microelements 